International Journal of English Literature and Social Sciences
Vol-6, Issue-5; Sep-Oct, 2021
Journal Home Page Available: $\underline{\text { https://ijels.com/ }}$ Journal DOI: $10.22161 /$ ijels

Peer-Reviewed Journal

\title{
Food culture and a Travelogue Nine fishy tales of Samanth Subramanian's Following Fish
}

\author{
Farddina Hussain
}

Associate Professor Department of English, Gauhati University, Assam, India

Received: 14 Aug 2021; Received in revised form: 11 Sep 2021; Accepted: 20 Sep 2021; Available online: 26 Sep 2021

C2021 The Author(s). Published by Infogain Publication. This is an open access article under the CC BY license

(https://creativecommons.org/licenses/by/4.0/).

\begin{abstract}
The paper reflects on fish as cuisine, medicine and commercial good following a 2010 travelogue by Samanth Subramanian. It argues how the peripheral socio-cultural space has evidently a long historical legacy despite the technological changes in the country creating a space on its own. It highlights slow food of the coastal areas as opposed to globalised consumerist consumptions of the metros. Globalisation has changed food cultures of India in addition to making resources available at all times irrespective of the specific seasonal bearings.
\end{abstract}

Keywords - Food humanities; Indian cuisine; Slow food; Travelogue; Alternative medicine.

Food and food culture is determined by the available resources at a given time and geographical area. This had been an obvious fact whenever we talk of food of a certain season or place. With globalisation and advance technologies however, cultures of consumption and availability has undergone a tremendous change.This is one of the issues taken up by Samanth Subramanian in his travelogue Following Fish. He informs of the community, their social and economic settings and their traditions.Travelogues help one to know about a place, its culture, society commerce, governance and its laws. Ibn Batuta, a passionate traveller of the $13^{\text {th }}$ century wrote on people, societies, political and economic conditions of the places he visited. In addition, he mentioned food, culinary terms, and kitchen utensils in his writings although some of them got lost due to theft while travelling, and an incident of a ship drowning in Kolkata India. So he had to write whatever he remembered of few of the places he visited. His travelogue have been important as first hand data to researches who wanted to know of his time and remote countries.

Subramanian's book published in 2010 traces a route of cultures of fish along the Indian coastal and occasionally in a landlock city of Hyderabad. The nine ways of looking at fish culminate in nine tales where he presents fish as food, health, culture, commerce and part of age old traditions. The stories qualify the places in terms of a food item that is fish. The author-traveller undertakes a journey through the diverse coastline of India tasting several fish curries and its presence in different walks of life and communities discussing their occupation, families and problems. He takes on the issues of environment and government policies that threaten old ways of livelihood of the fishing community by engaging in investigative journalism to discuss the various interventions in the coastal region.

As stated in the interview by NDTV, the author reveals that Kolkata's hilsa and Hyderabad's medicinal fish were the first obvious choices he thought of after he was assigned the writing project on travel and food. In the first chapter "On hunting the hilsa and mastering its bones" the author lands at Kolkata but it was not hilsa 'season' and many Bengali "classicists" suggested that he should come back during the monsoon to taste authentic hilsa: "The hilsa, they implied, is simultaneously a fish and a moral lesson: Good things come to those who wait" (Subramanian 2).

It was so integral to their identity that if Bengali cuisine were to be Wimbledon, hilsa would "always play on centre court". Poets have called it "darling of the waters"(ibid.). At the same time the fish also is the bone of contention for 
the people of East and West Bengal,and at the same time it has an economic link with Bangladesh. There's always a competition between the Ganga hilsa and the Padma hilsa. The Bengalis can touch and know the country or river from where it has been fished out. This commercial commodity lands up on the dining table on special occasions, family gatherings and festivals. He shows how fish gets into the life, culture and economics of the community in Kolkata.

The author -traveller describes not only the culture but also the way hilsa is cooked or sold in the Howrah market. He visits several shops and concludes "the long, magnificent necklace of India's coastline began, in a sense, here-perhaps, even from my little bench on the esplanade"(Subramanian 2) in Kolkata.

From Kolkata's hilsa to Malvan Mackerel, the travellerauthor tastes various fish curries and shows how they resonate lifestyles. Fish and alternative medicine has been one of the chapters, "On Swallowing a live Fish". The famous Hyderabadi 'fish treatment' for asthma is a wellknown fact. He provides an account that leads to the debate of using un-institutionalised traditional cure instead of modern day medical treatments: "In the early 2000s, this opposition began to hotly question everything about the treatment-its efficacy, its secrecy, its potential for harm, and its promotion by the Andhra Pradesh government" (Subramanian 24). But later the government had to put up a banner that the medicine had no curative value at the venue where the treatment takes place. Although, it is believed that "the treatment of something as elemental as asthma, which robs... of the very breathe of life, should be epic and enigmatic and miraculously curative" (Subramanian 21). The treatment dates back to the 1845 Bathini Goud family who is known to have treated thousands of patients and has it passed on to the next generations of males. But as the small murrel fish with the medicine inside its mouth goes down the throat of the patient the medicine is dispersed more easily "conveniently forgetting that asthma plagues the bronchial tubes, not the oesophagus" (Subramanian 22). At the same time the Goud family realises uncomfortably that due to fertilizers in food and air pollution, it could even take three or four years for the expected restored health. After several criticisms, public litigations against the treatment and the Gaud family members' failure to prove the paste as medicine in the line of modern scientific experimental drugs, they send it to Central Drug Research Institute in Lucknow and to the Institute of Chemical Biology in Kolkata who refused to comment on the drug's curative quality. The reports only stated it is not poison since it does not contain any metallic ingredient or hidden steroids and so "it is not believed to be a treatment since it does not take patient records, follow up visits and so unscientific and superstitious" (Subramanian 24). The treatment is more of a prasadam instead of a cure, linking it to religion. And religion in India informs of Indian culture - the food we eat, the clothes we wear, the festivals we celebrate, the classical music we listen to, the art and theatre we support" (Subramanian 27). In these confluences of traditional alternative cures, a space is created is mapped to highlight traditional healing ways in Indian society anddisplay the "roaring faith" of both the healer and the would-be healed.

This travelogue on Indian coastline differs from Dalrymple's approach in his travelogue Nine Liveswhere he documents the sacred, exotic India of yesteryears that lives on even if the nation-state moves rapidly towards technology. Subramanian explicitly displays his perceptions of the eco-cultural landscape by representing and commenting on what he sees and learns from the locals. For instance, Goa turns out to be "a state that had come to be unfortunately infected with the idleness of its guests" (Subramanian 127) where tourism industry has brought in serious environmental crisis and re-distribution of income and capital in a consumer's paradise where land and sea has been commodified. The author locates within this setting people who still believes and attempts at living old Goan life of leisure and fishing days. The contest between the ever growing tourism industry and fishing business, although "really no contest at all", has kept the fish away from the disturbing waters: There used to be twenty to twenty-five fishing boats at a time on Baga beach, but now there are barely a couple" (Subramanian 116), deprived of the space and so the fisherman turns to tourism businesses of water sport, hotels and renting shacks on the beaches. Moreover the improved roadways brought in more fish from the neighbouring states and locals lament the loss of a "dystopian fishing culture to the larger loss of an old Goa” (Subramanian 115).

One important issue raised by Tuan in his essay "Perception and Cultural Geography" is "Should we depend on the past so much for our sense of the past because past is palimpsest and palimpsests are of unequal quality?'. Some people's ancestors might have failed to leave their mark. But something like a cult of the past has infected both developed and developing countries that takes different forms: religious fundamentalism, ethnic pride--the pride of minority groups in their culture within a society dominated by transnational commerce and high technology, pride of formerly colonized peoples in their pre-colonial past - cultural fundamentalism; fourth a quasi religious environmentalism that posits organic wholeness and virtue in the pristine past; the fifth being a playful interest in genealogy and heritage - the past as hobby (Tuan2003 879). Subramanian's travelogue records the 
pride of regional past ethnic cultures and food-style and their changes on the face of productivity and commerce. In Kolkata the pride of Bengali identity hilsa is now available at all times, although its season is believed to be in February, because of its culinary demand and commercial gain whereas the "eco-savvy Bengalis of earlier centuries constructed the idea of the hilsa 'season' and buckled it to the religious calendar only to avoid overfishing" (Subramanian 3). Also locals lament the deterioration of the hilsa due to "the increasingly muddied and polluted Ganga" and the Hooghly a "densely polluted, choked river" now (Subramanian 13). He notices the fisherman's quiet complaints against modernity and the son's aiming for, instead of fishing as an occupation, white collared jobs. The fishermen might have replaced the compass and oars with GPS and engines and they are "the last remaining people to work closely and daily in an untamed natural world"1 (Subramanian 165) but fishing remains as the most elemental exercise consisting of water, air, light and space. Coastal periphery houses the paradox: traditional fishing communities moving away from their trade, and commercial businessmen fill harbours and ports capacity with motorized fishing boats or trawlers ignoring overfishing and coastal pollution.

The productions of space in Subramanian's travelogue in terms of economic gains merge the traditional with the modern in an unhappy coming together of spaces. The lore of cultural geography reveals much that is traditional, but a persistent restlessness lurks there, "and what has been accomplished is but a prelude to what might be accomplished. Never perfect, but always perfectable, cultural geography is perhaps best defined as an unfinished task" (Mikesell 16). It can be more than good journalism, and as Tuan foresees "should also address issues that are not at the top of society's present agenda" (Tuan). The travelogue is a journalistic reportage of the peripheral space that he chooses to depict. He sees India with its multi-modern ways based on the economic and cultural life of the people.

Consequently, similar to what Nandy in his Intimate Enemy writes, it is not possible to reconceptualise India as only a nation-state with a single identifiable national culture and identity. Trying to convert India into a globalised western style state will further complicate local identities of culture, religion and India's recent economic globalisation encourage the national discourse of defining the country even more rigidly and narrowly:

"It took India sixty years to become what it is today, and it will be probably another sixty years before India realises

\footnotetext{
${ }^{1}$ As the author believes farmers have controlled their land or tilled it into submission
}

that it should have followed the Gandhian path. From cars to computers, Indian consumers, orientated to the personalisation of goods and services, have embraced the allure of a modern society that is uninterested in tradition. To this dichotomy we may add a second: the gap between the metropolises and the countryside. There is a yawning chasm between the glittery upper-class lifestyle of the cities and grinding rural poverty. (Nandy 4)

Globalisation had reduced India's options of traditional practices of the people in the periphery. It has distanced the local placemaking-- cultural place by emphasising more on information technology and productivity. Economic reforms have turned the nation into a consumer based society where speed, productivity, progress are the fundamental markers - a notion that Gandhi challenged during his lifetime. Jahanbegloo asserts in his book that recent Indian governments have neglected his vision and has been Gandhian in their promises but not practically. They did not follow him at the moral and creative level of economic justice and non-violence. Concurrently Indians' awareness of these Gandhian ideologies also made some to re-think and revisit the idea of this nation; the sacred, India's spiritual legacy in folk traditions, story-telling and local cultures.

The one identity that India always had is of a plural self. In spite of the changes and development as Dalrymple asserts of in his book, an older India endures and the same existential quandaries trouble them like the holy men of ancient India. They search for a life of spirituality instead of material success and comfort. The travelogue by Dalrymple was in fact initiated by his encounter with a software engineer who had become a sanyasi. Before this meeting Dalrymple assumed that most of the Holy men in India were from traditional rural backgrounds motivated by their unflinching faith. This Ajay Kumar Jha was an MBA from Patna university and considered to be a highflyer by his employers. He simply asserted that: '...one day I just decided I could not spend the rest of my life marketing fans and fridges. So I just left. I wrote a letter to my boss and to my parents, gave away my belongings to the poor, and took a train to Benares. There I threw away my old suit, rubbed ash on my body and found a monastery.' (Dalrymple $\mathrm{x}$ ) This experience "where a committed, naked sadhu can also be an MBA" surprised him and he began thinking what Indian philosophy and spiritual life has to offer to the world; therefore he decides on a journey in search of spiritual India that exists in a non-modern space. It is this discovery and experience which Dalrymple reports in his travelogue. Re-presentation of this space engages his ability to understand, imagine and articulate within a frame the nine life stories following the Indian art of story-telling which can be palimpsest. It is 
a world where Dalrymple projects out of his experience knowledge of the field through interviews, watching performances and visiting shrines and ashrams.

The travelogues create an epistemology based on 'experience knowledge' of the writers who travel to distant areas and chart on a space that need to enter into a dialogue with the state to form an idea of plural India where being oneself also meant hosting within one's self the otherness of others. In Following Fish, it is through participation and dialogues he recordsthe idea of multiple Indias.

Winston Churchill had once said that India is 'a geographical expression' (Jahanbegloo 2) than a temporal one. Experience knowledge is ultimately related to national identity. These travelogues, Dalrymple's or Subramanian's bring into account firsthand experiences and mapsthese geographical spaces.The diverse nonmodern beliefs, people and their cultureis what, as Foucault suggests in 1991 the definition of government is; in no way, it governs a territory alone, it also governs things. Machiavelli's The Prince offered not military defence alone but also political shrewdness and cover. Foucault emphasis to a more nuanced notion of government over men and things, constitutes a population of a nation rather than a simple retention of territorial control. A population is not just a sum of individuals inhabiting a territory but an object itself with birth and death rates:

I think it is not a matter of opposing things to men, but rather of showing that what government has to do with is not territory but, rather, a sort of complex composed of men and things...men in their relations, their links, their imbrications with those things that are wealth, resources, means of subsistence, the territory with its specific qualities, climate, irrigation, fertility, and so on...what counts is essentially this complex of men and things; property and territory are merely one of its variables. (Foucault)

So the art of government is less about geopolitics but more deeply geographical, enabling a new form of cartography. India too has to hold on together despite its multifaceted realities- an original, primal or indigenous and the other of change but no single unit or dimension can be complete or static as an image of India. The authors of both the travelogues chart a trajectory in locating and writing of a space that is not to highlight the state's ideological discourse but strive to maintain a concept of culture of few communities and as Tuan writes:

My parting advice to the next generation of cultural geographers is that they, against the spirit of the time, strive to maintain a concept of culture that is not reducible to self-centered manoeuvring and power struggle; and that they see culture not only what all or most people do, but also what a few individuals do exceptionally well, with lasting consequences_-good and ill-for their fellow humans. (Tuan 2004 733)

\section{REFERENCES}

[1] Mikesell, Marvin W. "Tradition and Innovation in Cultural Geography" Annals of the Association of American Geographers, Vol. 68, No. 1(Mar., 1978), pp. 1-16. Taylor \& Francis, Ltd. Stable URL: http://www.jstor.org/stable/2569143.

[2] Nandy. Ashis, The Intimate Enemy: Loss and Recovery of Self under Colonialism. OUP (Fourth Impression), New Delhi: 2010.

[3] Price, Marie and Lewis, Martin. "The Reinvention of Cultural Geography" Annals of the Association of American Geographers, Vol. 83, No. 1 (Mar., 1993), pp. 117. Taylor \& Francis, Ltd. Stable URL: http://www.jstor.org/stable/2569413.

[4] Robinson, Brian and Tuan, Yi-Fu. "On "Surface Phenomenon and Aesthetic Experience" by Tuan" Annals of the Association of American Geographers, Vol. 80, No. 3 (Sept., 1990), pp. 455-457, Taylor \& Francis, Ltd. Stable URL: http://www.jstor.org/stable/2563625

[5] Subramanian. Subramanian, Following Fish: Travels Around The Indian Coast. Penguin Books India: 2010.

[6] Yi Fu. Tuan,"Perceptual and Cultural Geography: A Commentary". Annals of the Association of American Geographers, Vol. 93, No. 4 (Dec., 2003), pp. 878-881 Taylor \& Francis, Ltd. Stable URL: http://www.jstor.org/stable/1515357

[7] ------"Cultural Geography: Glances Backward and Forward", Annals of the Association of American Geographers, Vol. 94, No. 4 (Dec., 2004), pp. 729-733, Taylor \& Francis, Ltd. Stable URL: http://www.jstor.org/stable/3694090. 